\title{
Questionnaires that measure the quality of relationships between patients and primary care providers: a systematic review
}

\author{
Lauren E. Ball ${ }^{12^{*}} \mathbb{D}$, Katelyn A. Barnes ${ }^{2}$, Lisa Crossland ${ }^{1}$, Caroline Nicholson ${ }^{1}$ and Claire Jackson ${ }^{1}$
}

\begin{abstract}
Background: International guidance on models of care stress the importance of good quality, continuous patientprovider relationships to support high quality and efficient care and hospital avoidance. However, assessing the quality of patient-provider relationships is challenging due to its experiential nature. The aim of this study was to undertake a systematic review to identify questionnaires previously developed or used to assess the quality of continuous relationships between patients and their provider in primary care.

Methods: MEDLINE, PubMed, Cumulative Index of Nursing and Allied Health Literature (CINAHL) and SCOPUS databases were searched for English language studies published between 2009 and 2017. Key terms used identified studies conducted in the primary care setting examining relationships between patients and providers. Studies that focused on the conceptualisation, development, testing or review of a questionnaire, or studies that used a questionnaire for assessing the quality of continuous relationships between patients and providers were eligible. Studies that did not assess quality via a questionnaire, only assessed single aspects of relationships, only assessed single encounters, assessed transitions between settings or assessed relationships using an index were excluded. Information on validity testing of each relevant questionnaire identified from articles was reviewed to inform recommendations for future research and evaluation.
\end{abstract}

Results: Twenty-seven studies met the eligibility criteria, including 14 unique questionnaires. The questionnaires were diverse in length, scope, focus and level of validity testing. Five questionnaires were considered not feasible for future use due to size and lack of development work. Three questionnaires were considered strongest candidates for use in future work based on being relevant to the topic and primary care setting, freely available in English and not needing additional pilot work prior to use. These three questionnaires were the Care Continuity Across Levels of Care Scale, the Nijmegan Continuity Questionnaire and the Patient-Doctor Depth of Relationship Tool.

Conclusions: This study provides an overview of 14 unique questionnaires that have been used to assess the quality of continuous relationships between patients and primary care providers. The decision to use one of the questionnaires in future work requires careful consideration, including the scope, length, validation testing, accessibility of the questionnaires and their alignment with the initiative being evaluated.

Keywords: Continuity of care, General practice, Physician-patient relations, Primary care, Relationships, Survey, Therapeutic Alliance, Questionnaire

\footnotetext{
* Correspondence: I.ball@griffith.edu.au

${ }^{1}$ Centre for Health System Reform and Integration, UQ-Mater Research Institute, Brisbane, Australia

${ }^{2}$ Menzies Health Institute Queensland, Griffith University, Parklands Drive,

Southport, Gold Coast, QLD 4222, Australia
}

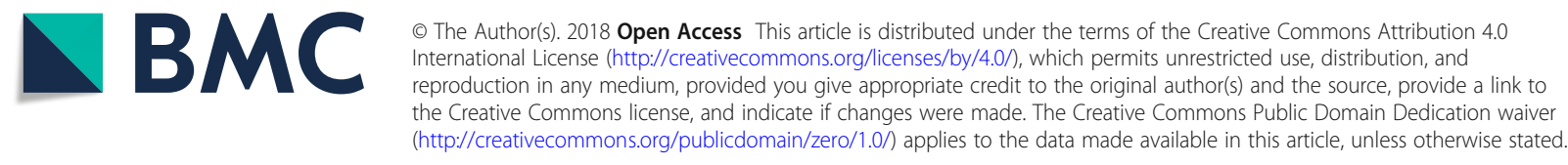




\section{Background}

The focus of primary care is changing in many countries, with the aging of populations and growing need for continuity rather than episodic care. Structural reforms such as the 'Patient-Centered Medical Home' (North America) and 'Health Care Home' (Australia \& New Zealand) are helping services move away from transaction-based care towards care that is patient-centred and continuous $[1,2]$. This change in focus emphasises the importance of all patients having a high-quality relationship with a primary care provider that continues over time [2]. 'Continuity of Care' has seemingly been associated with improved clinical outcomes, but the critical elements in play remain undescribed. Concepts such as therapeutic alliance [3], working alliance [4], continuity of care [5], relational continuity [6] and relationship-based care [7] describe the positive outcomes that occur when a patient has a sense of affiliation, collaboration and trust with a single provider that is ongoing in nature [8]. These high-quality relationships have been shown to result in positive patient experiences, greater patient satisfaction, increased treatment adherence and improved patient outcomes [3, 4, 9]. Supporting these continuous, high-quality relationships is clearly warranted.

Assessing the quality of relationship between patients and providers is challenging due to its experiential nature. There is no universal agreement about the definition of quality relationships or the components that underpin the concept, making it challenging to develop valid and reliable assessment tools (questionnaires). Furthermore, the quality of relationships between patients and providers is thought to be influenced by demographic factors of the patient and provider, role of medical receptionists and other staff, and organisational factors of general practice clinics [5]. It is therefore not surprising that quality of relationship is one of the least commonly evaluated aspects of care and there is no recommendation on how to evaluate relationship quality within the reforms happening to general practice $[10,11]$.

A systematic review has previously been conducted to identify questionnaires that can be used to assess the quality of relationships between patients and doctors across all health care settings [12]. The search was conducted in 2009 and nineteen tools were identified, with variable levels of validity testing to support their development. The review methodology provided a wide reach of measures to consider, but none of the questionnaires were developed for use in the primary care setting where the majority of patients and families experience ongoing care. As a result, there is still no best approach recommended for primary care and the feasibility of these reviewed measures, whilst important, is unknown.

The aim of this study was to conduct a systematic review of the body of evidence for studies that measure the quality of continuous relationships between patients and primary care providers. The review will identify questionnaires developed or used since the previous systematic review [12] and will also appraise the questionnaires on their validity and feasibility for use in the primary care setting. The review will inform evaluation strategies for health care homes.

\section{Methods}

\section{Overview}

A systematic review was conducted to identify measures of continuous quality relationships between patients and providers in primary health care. For the purpose of the review, 'relationships' referred to an ongoing sense of affiliation and collaboration with a provider in primary care, typically a General Practitioner (GP) [8]. The systematic review was conducted in accordance with the Preferred Reporting Items for Systematic reviews and Meta Analyses (PRISMA) statement [13].

\section{Literature search}

A systematic computer-based literature search was conducted between March and June 2017. Databases searched were MEDLINE, PubMed, Cumulative Index of Nursing and Allied Health Literature (CINAHL) and SCOPUS. Medical subject headings (MeSH), were used in the execution of PubMed and MEDLINE database searches. Boolean connectors AND and OR were used to combine search terms. Three categories of search terms were used; (i) terms relating to the setting: 'primary care,' 'primary health care' and 'general practice', (ii) terms relating to relationships: 'relational continuity', 'continuity of care,' 'physician-patient relations,' 'professional-patient relations,' 'therapeutic alliance,' patient participation', and 'patient empowerment', and (iii) terms relating to the methodological focus of the study: 'tool', 'instrument', 'scale, 'survey', 'questionnaire' and 'measure'. Google Scholar and PUBMED were used to obtain additional articles identified by journal hand searching. All database search results were imported into EndNote and duplicates removed prior to screening.

\section{Eligibility criteria}

Studies were included in the review if: 1) they focused on the conceptualisation, development, testing or review of a questionnaire for measuring the quality of continuous relationships between patients and a primary care provider; or 2) they used a questionnaire for assessing the quality of continuous relationships between patients and a primary care provider. Studies were also included if the authors' interpretation of "relationships" related to patients having a sense of affiliation, collaboration and trust with a single provider that is ongoing in nature, including phrases such as therapeutic alliance, working 
alliance, continuity of care and relational continuity. All study designs were considered relevant, including observational, descriptive, intervention and theoretical methodologies. Studies needed to be available in full-text, English and published between the years 2009-2017. This time period was chosen because the literature search in the previous systematic review related to this topic occurred in 2009 [12]. The focus on health care homes as an approach to primary health care reform has also occurred since this time [1].

Studies were excluded if they described the importance of high quality relationships without measuring or assessing these (i.e. via a questionnaire). All remaining studies that utilised a questionnaire were excluded if the questionnaire assessed: (1) single encounters only (rather than continuous care), (2) single aspects of relationships (such as communication), (3) transitions between health care settings (such as attending primary care after hospital discharge; informational continuity) or (4) assessed the quality of relationships between providers in a multidisciplinary team. Finally, studies that used a formulaic index to assess relationships (such as the number of different providers seen in a year) were also excluded due to the inability to assess the quality of relationships using this approach.

\section{Study selection}

The study selection process is illustrated in Fig. 1. A quality control training procedure was conducted to ensure consistency of coding between reviewers. Three reviewers independently read the abstracts of the first 100 articles identified in the search and coded them as 'retrieve full text' if the article met the inclusion criteria; 'exclude' if the article did not meet the eligibility criteria or 'unsure' if the reviewer was not able to make a decision. Agreement between all reviewers was obtained for $62 / 100$ abstracts (62\%), and at least one reviewer coded 'unsure' for the remainder of articles. Where the coding differed, consensus was achieved through group discussion. Another 50 abstracts were then reviewed and coded independently, with agreement for 46/50 (92\%) abstracts obtained. Following another group discussion, the remaining abstracts were divided between the three reviewers for independent, duplicate coding.

Full manuscripts were retrieved for those studies coded by two reviewers to meet the inclusion criteria or where more information was required in order to make a decision. Disagreements between duplicate reviewers were considered by the third reviewer and resolved via group discussion. Reference lists from all systematic review articles retrieved but not included were cross-checked to identify

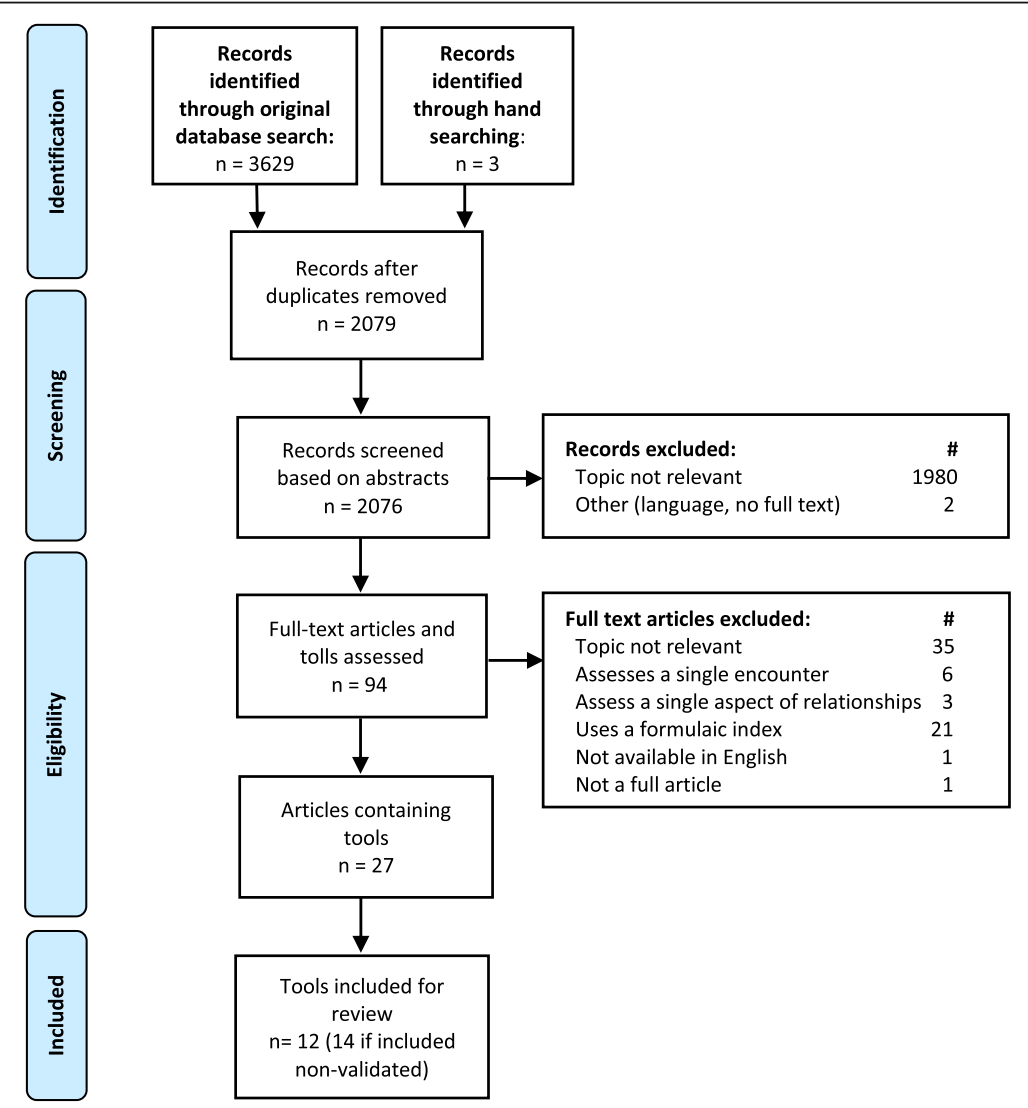

Fig. 1 PRISMA diagram of the literature search and filtering results for a systematic review of the questionnaires used to measure continuous relationships in primary care 
additional articles not captured in the original search. These studies were subjected to identical abstract review.

\section{Data extraction}

Data from all included articles were extracted using an electronic spread sheet developed specifically for this review. Information extracted included authorship team; year of publication; country; stated aim; participant characteristics (age, sex and relevant health conditions); phrases used to indicate its relevance to the review topic; and relevant tools used in the study. For each questionnaire, information about the name, author, number of items, answer format, target respondents and validation activities were extracted into a separate electronic spread sheet. Hand searching was conducted on each questionnaire to identify information not provided in the reviewed article, including validation work.

\section{Risk of bias and data analysis}

Quality assessment of included articles was not undertaken for this review as it does not draw conclusions from the findings of the articles. Rather, information on validity testing of questionnaires was extracted, covering internal consistency, construct validity, test-retest reliability, face validity, and test discriminate validity. This information was analysed by two reviewers using an iterative process of data extraction, discussions and contacting authors of questionnaires where required. Decisions about the appropriateness of questionnaires to primary health care were made in group meetings after considering the focus, length, validation and availability.

\section{Results}

The initial database search identified 3629 articles for screening as outlined in Fig. 1. Within this group, four systematic reviews were screened and although none met the inclusion criteria, their reference lists identified an additional three articles for consideration. After removing duplicate copies of articles, the main reasons for excluding articles were: the topic not being relevant $(n=2015)$; the study using a formulaic index to assess relationships $(n=21)$; the study examining single encounters only $(n=6)$, the study examining single aspects of relationships such as communication $(n=3)$; or the study not being available in full-text in English $(n=4)$. This left 27 studies eligible for inclusion.

Table 1 outlines the characteristics of the 27 studies included in the review. Of the 27 studies, eight studies focused on the conceptualisation, development, testing or review of a questionnaire [14-21] and 19 studies used a questionnaire in a study investigating the quality of relationships between patients and primary care providers $[6,19,22-38]$. The following phrases were used in the studies to refer to "quality of relationships" and considered synonymous with the topic of this review: care continuity, continuing relationship, continuity of care, interpersonal care, long term relationships, longitudinality of care, patient-doctor relationships, patient-provider relationships, personal continuity, quality of care, relational continuity, relations, therapeutic alliance, therapeutic relationship.

Some questionnaires were used in several of the studies. Therefore, although 27 studies were included in the review, only 14 questionnaires were used. Table 2 summarises the 14 relevant questionnaires used in the studies. Three of the questionnaires (Primary Care Assessment Survey; Primary Care Assessment Tool; Primary Care Evaluation Tool) were large instruments investigating multiple components of quality care, with only a very small section (e.g. one subscale) examining quality of relationships. These questionnaires were considered unfeasible for future use because most of the data would be irrelevant to the topic. Also, they would require substantial time (e.g. $45 \mathrm{~min}$ for the Primary Care Assessment Survey) to complete the questionnaire. Two of the questionnaires (neither with a name) were developed only for use in the reviewed study and were not pilot tested for the purpose of others' utilising the questionnaires in work [22, 28]. These two questionnaires were considered unfeasible for future use as there was no evidence to support their validity. This left nine questionnaires that were examined further.

Table 3 provides information on the feasibility of using the nine remaining questionnaires. The questionnaires are diverse in length; the shortest being the Therapeutic Bond Scale ( 6 items; $30 \mathrm{~s}$ to complete) and the longest being the Care Continuity Across Levels of Care Scale (73 items, up to $15 \mathrm{~min}$ to complete). Some of the questionnaires focus entirely on assessing quality of relationships, such as Patient-Doctor Relationship Questionnaire (100\% relevant items). However, for other questionnaires, relationship quality is not the only focus, such as the Generic Measure of Continuity Scale (34\% relevant items) and Nijmegan Continuity Questionnaire (28\% relevant items). Seven of the questionnaires are freely available for use, whereas the Generic Measure of Continuity Scale and Therapeutic Bond Scale requires payment prior to use. All the questionnaires are in the English language, with several also translated to other languages.

\section{Discussion}

This study systematically reviewed the body of evidence to address the lack of understanding on how to best measure the quality of continuous relationships between patients and primary care providers. Fourteen relevant questionnaires were found in the 27 studies included in the review. Of the 14 questionnaires, nine were considered as potentially feasible for future use, including three that were considered strongest candidates based on being relevant, freely available in English and not needing 
Table 1 Characteristics of included studies assessing the quality of continuous relationships between patients and providers in primary care grouped by inclusion criteria and in alphabetical order of first author

\begin{tabular}{|c|c|c|c|c|c|c|}
\hline Author (Year) & Country & Aim of study & $\begin{array}{l}\text { Sample } \\
\text { (Participants) }\end{array}$ & $\begin{array}{l}\text { Phrases used to } \\
\text { indicate "quality } \\
\text { relationships" }\end{array}$ & $\begin{array}{l}\text { Type of } \\
\text { relevant } \\
\text { questionnaire(s) }\end{array}$ & $\begin{array}{l}\text { Name of } \\
\text { relevant } \\
\text { questionnaire(s) }\end{array}$ \\
\hline
\end{tabular}

Studies about the conceptualisation, development, testing, or review of a tool for assessing the quality of relationships between patients and providers in primary care

\begin{tabular}{|c|c|c|}
\hline $\begin{array}{l}\text { Burge et al. } \\
\text { (2011) [14] }\end{array}$ & Canada & $\begin{array}{l}\text { To examine how well relational } \\
\text { continuity is measured in } \\
\text { validated instruments that } \\
\text { evaluate primary healthcare } \\
\text { from the patient's perspective. }\end{array}$ \\
\hline
\end{tabular}

Haggerty et al. Canada
(2012) [15]

(1)

Harley (2009) England
$[16]$

Hill et al. $\quad$ England
(2014) $[17] \quad$

(2014) [17]

Jatrana (2011)

[18]

$$
\text { New }
$$$$
\text { Zealand }
$$

To develop and validate a generic measure of management continuity from the patient perspective.

To adapt the Components of Primary Care Index (CPCI) to outpatients and to assess the reliability and validity of the adapted instrument (renamed the Medical Care Questionnaire [MCQ]).

To determine the suitability of the Primary Care Assessment Tool as a measure of continuity of care for patients with a long-term condition (stroke), and co-morbidity, in a primary care setting.

To construct a summary measure of continuity of care be applicable to oncology

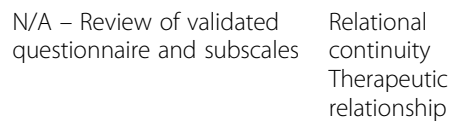

Patients who had received care for an ongoing health condition at more than one clinic in the previous 12 months.

\section{Outpatient cancer patients} $\geq 18$ years of age.

Community living stroke survivors (12 months post stroke)

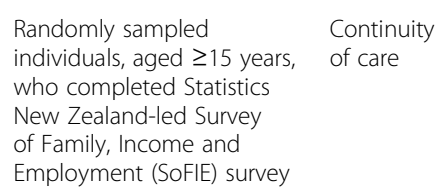

Continuity

of care

Patients aged $>18$ years, with at least one chronic illness, literate in Dutch. generic questionnaire to measure continuity of care from the patient's perspective across primary and secondary care settings.

$\begin{array}{ll}\begin{array}{l}\text { Uijen (2012) Netherlands } \\ \text { [40] }\end{array} & \begin{array}{l}\text { To further examine the validity, } \\ \text { discriminative ability, and } \\ \text { reliability of the Nijmegen } \\ \text { continuity questionnaire. }\end{array} \\ \text { Zenger (2014) Germany } & \begin{array}{l}\text { To assess the internal and } \\ \text { external validity of the German } \\ \text { version of the PDRQ-9 in a } \\ \text { representative cross-sectional } \\ \text { German population }\end{array}\end{array}$

Studies that use a tool for assessing the quality of relationships between patients and providers in primary care

\begin{tabular}{|c|c|c|}
\hline $\begin{array}{l}\text { Al-Azri et al. } \\
(2014)[22]\end{array}$ & Oman & $\begin{array}{l}\text { To study the role of relational } \\
\text { continuity in primary care } \\
\text { settings and its effect on } \\
\text { patients' perceptions and } \\
\text { experiences. }\end{array}$ \\
\hline $\begin{array}{l}\text { Bryan et al. (2012) } \\
\text { [24] }\end{array}$ & $\begin{array}{l}\text { United States of } \\
\text { America }\end{array}$ & $\begin{array}{l}\text { To identify the impact of very } \\
\text { early therapeutic alliance } \\
\text { on the general trajectory of } \\
\text { change for suicidal ideation }\end{array}$ \\
\hline
\end{tabular}

Relational continuity

Continuity

of care

Coordination

of care
Continuity

of care

Relational

continuity

Patients aged $>18$ years, with at least one chronic illness, literate in Dutch.

Continuity

of care

Personal

continuity

Quality of care

Randomly selected individuals, $\geq 14$ years of age, literate in German,

Patient-doctor relationship, therapeutic alliance,
Patients aged $>18$ years
attending their $\mathrm{PCHCs}$ during the study period

Patients with mental health concerns, receiving a referral from their primary care provider to an

$\begin{array}{ll}\begin{array}{ll}\text { Validated } \\ \text { questionnaires }\end{array} & \begin{array}{l}\text { Primary Care } \\ \text { Assessment } \\ \text { Survey } \\ \text { Primary Care } \\ \text { Assessment Tool } \\ \text { (short form) } \\ \text { Components of } \\ \text { Primary Care Index }\end{array} \\ \begin{array}{ll}\text { Questionnaire } \\ \text { (being validated) }\end{array} & \begin{array}{l}\text { Generic measure } \\ \text { of continuity } \\ \text { of care }\end{array} \\ & \\ \text { Questionnaire } & \text { Medical Care } \\ & \text { Questionnaire }\end{array}$

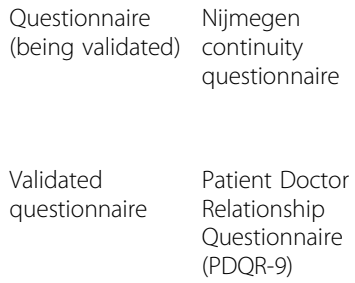

Validated questionnaire

\section{Patient Doctor} Relationship Questionnaire (PDQR-9)

Relational continuity

Non-validated questionnaire

N/A

Therapeutic alliance
Validated questionnaire
Therapeutic Bond Scale 
Table 1 Characteristics of included studies assessing the quality of continuous relationships between patients and providers in primary care grouped by inclusion criteria and in alphabetical order of first author (Continued)

\begin{tabular}{|c|c|c|c|c|c|c|}
\hline Author (Year) & Country & Aim of study & $\begin{array}{l}\text { Sample } \\
\text { (Participants) }\end{array}$ & $\begin{array}{l}\text { Phrases used to } \\
\text { indicate "quality } \\
\text { relationships" }\end{array}$ & $\begin{array}{l}\text { Type of } \\
\text { relevant } \\
\text { questionnaire(s) }\end{array}$ & $\begin{array}{l}\text { Name of } \\
\text { relevant } \\
\text { questionnaire(s) }\end{array}$ \\
\hline & & $\begin{array}{l}\text { among patients seen within } \\
\text { the context of an integrated } \\
\text { primary care behavioural } \\
\text { health service. }\end{array}$ & $\begin{array}{l}\text { Air-Force hospital based } \\
\text { Behavioural Health } \\
\text { Consultant. }\end{array}$ & & & \\
\hline $\begin{array}{l}\text { Corso et al. } \\
\text { (2012) [25] }\end{array}$ & $\begin{array}{l}\text { United } \\
\text { States of } \\
\text { America }\end{array}$ & $\begin{array}{l}\text { To investigate therapeutic } \\
\text { alliance and clinical } \\
\text { improvement within an } \\
\text { integrated primary care } \\
\text { behavioural health model }\end{array}$ & $\begin{array}{l}\text { Patients with mental health } \\
\text { concerns receiving a referral } \\
\text { from their primary care } \\
\text { provider to an Air-Force } \\
\text { hospital based Behavioural } \\
\text { Health Consultant. }\end{array}$ & $\begin{array}{l}\text { Therapeutic } \\
\text { alliance }\end{array}$ & $\begin{array}{l}\text { Validated } \\
\text { questionnaire }\end{array}$ & $\begin{array}{l}\text { Therapeutic } \\
\text { Bond Scale }\end{array}$ \\
\hline $\begin{array}{l}\text { Falkenström } \\
\text { et al. (2013) } \\
\text { [26] }\end{array}$ & Sweden & $\begin{array}{l}\text { Test whether high alliance } \\
\text { scores after a consultation } \\
\text { predicts lower symptom } \\
\text { scores immediately before } \\
\text { the next consultation }\end{array}$ & $\begin{array}{l}\text { Patients aged } 18-70 \text { years, } \\
\text { attending a health service } \\
\text { and receiving treatment } \\
\text { with psychologist, social } \\
\text { worker or counsellor }\end{array}$ & $\begin{array}{l}\text { Therapeutic } \\
\text { alliance }\end{array}$ & $\begin{array}{l}\text { Validated } \\
\text { questionnaire }\end{array}$ & $\begin{array}{l}\text { Working Alliance } \\
\text { Inventory, short } \\
\text { form (revised) }\end{array}$ \\
\hline $\begin{array}{l}\text { Ferrer et al. } \\
\text { (2014) [27] }\end{array}$ & Brazil & $\begin{array}{l}\text { To compare two offered care } \\
\text { models in relation to } \\
\text { longitudinality care, from } \\
\text { the users' perspective, and to } \\
\text { correlate this finding to the } \\
\text { utilisation of PHC services } \\
\text { among patients hospitalised } \\
\text { due to preventable conditions. }\end{array}$ & $\begin{array}{l}\text { Children aged } 0-14 \text { years, } \\
\text { attending paediatric ward } \\
\text { of Sao Paulo hospital } \\
\text { during the study period }\end{array}$ & $\begin{array}{l}\text { Longitudinally } \\
\text { of care } \\
\text { Care continuity }\end{array}$ & $\begin{array}{l}\text { Validated } \\
\text { questionnaire }\end{array}$ & $\begin{array}{l}\text { Primary Care } \\
\text { Assessment Tool } \\
\text { (child version) }\end{array}$ \\
\hline $\begin{array}{l}\text { Hansen (2016) } \\
{[28]}\end{array}$ & Norway & $\begin{array}{l}\text { To explore how women with } \\
\text { CFS/ME experience GP care } \\
\text { regarding informational, } \\
\text { management, and } \\
\text { relational continuity. }\end{array}$ & $\begin{array}{l}\text { Members of the Norwegian } \\
\text { Myalgic Encephalomyelitis } \\
\text { association, experiencing } \\
\text { Chronic Fatigue Syndrome }\end{array}$ & $\begin{array}{l}\text { Relational } \\
\text { continuity }\end{array}$ & $\begin{array}{l}\text { Non-validated } \\
\text { questionnaire }\end{array}$ & N/A \\
\hline $\begin{array}{l}\text { Hernandez, A. } \\
\text { et al. (2013)a } \\
\text { [29] }\end{array}$ & $\begin{array}{l}\text { Spain / } \\
\text { Catalonia }\end{array}$ & $\begin{array}{l}\text { To determine patients' } \\
\text { perceived degree of continuity } \\
\text { of care between primary and } \\
\text { secondary care and to identify } \\
\text { contextual and individual } \\
\text { factors that influence patients' } \\
\text { perceptions of continuity } \\
\text { of care. }\end{array}$ & $\begin{array}{l}\text { Patients } \geq 18 \text { years of age } \\
\text { who had received primary } \\
\text { and secondary care in } \\
\text { Catalonia within the } \\
\text { previous } 3 \text { months. }\end{array}$ & $\begin{array}{l}\text { Relational } \\
\text { continuity }\end{array}$ & $\begin{array}{l}\text { Validated } \\
\text { Questionnaire }\end{array}$ & $\begin{array}{l}\text { Care Continuity } \\
\text { Across Levels of } \\
\text { Care Scale } \\
\text { (CCAENA) }\end{array}$ \\
\hline $\begin{array}{l}\text { Hernandez, A. } \\
\text { et al. (2013)b } \\
{[30]}\end{array}$ & $\begin{array}{l}\text { Spain / } \\
\text { Catalonia }\end{array}$ & $\begin{array}{l}\text { To compare immigrants' and } \\
\text { natives' perceptions of } \\
\text { relational, managerial and } \\
\text { informational continuity of } \\
\text { care and to explore the } \\
\text { influence of the length of stay } \\
\text { on perceptions of continuity. }\end{array}$ & $\begin{array}{l}\text { Patients } \geq 18 \text { years of age } \\
\text { who had received primary } \\
\text { and secondary care in } \\
\text { Catalonia within the } \\
\text { previous } 3 \text { months. }\end{array}$ & $\begin{array}{l}\text { Relational } \\
\text { continuity }\end{array}$ & $\begin{array}{l}\text { Validated } \\
\text { Questionnaire }\end{array}$ & $\begin{array}{l}\text { Care Continuity } \\
\text { Across Levels of } \\
\text { Care Scale } \\
\text { (CCAENA) }\end{array}$ \\
\hline $\begin{array}{l}\text { Hernandez, A. } \\
\text { et al. }(2013) \text { c } \\
\text { [31] }\end{array}$ & $\begin{array}{l}\text { Spain / } \\
\text { Catalonia }\end{array}$ & $\begin{array}{l}\text { To provide additional evidence } \\
\text { on the psychometric } \\
\text { properties the scales of } \\
\text { this questionnaire. }\end{array}$ & $\begin{array}{l}\text { Patients } \geq 18 \text { years of age } \\
\text { who had received primary } \\
\text { and secondary care in } \\
\text { Catalonia within the } \\
\text { previous } 3 \text { months. }\end{array}$ & $\begin{array}{l}\text { Patient-primary } \\
\text { care provider } \\
\text { relationship, } \\
\text { Continuity } \\
\text { across care }\end{array}$ & $\begin{array}{l}\text { Validated } \\
\text { Questionnaire }\end{array}$ & $\begin{array}{l}\text { Care Continuity } \\
\text { Across Levels } \\
\text { of Care Scale } \\
\text { (CCAENA) }\end{array}$ \\
\hline $\begin{array}{l}\text { Hernandez, A. } \\
\text { et al. (2013)d } \\
\text { [31] }\end{array}$ & $\begin{array}{l}\text { Spain / } \\
\text { Catalonia }\end{array}$ & $\begin{array}{l}\text { To analyse patient's reported } \\
\text { elements of relational, } \\
\text { informational and managerial } \\
\text { (dis)continuity between } \\
\text { primary and outpatient } \\
\text { secondary care and to } \\
\text { identify associated factors. }\end{array}$ & $\begin{array}{l}\text { Patients } \geq 18 \text { years of age } \\
\text { who had received primary } \\
\text { and secondary care in } \\
\text { Catalonia within the } \\
\text { previous } 3 \text { months. }\end{array}$ & $\begin{array}{l}\text { Relational } \\
\text { (dis)continuity }\end{array}$ & $\begin{array}{l}\text { Validated } \\
\text { Questionnaire }\end{array}$ & $\begin{array}{l}\text { Care Continuity } \\
\text { Across Levels of } \\
\text { Care Scale } \\
\text { (CCAENA) }\end{array}$ \\
\hline $\begin{array}{l}\text { Hernandez, SE. et al. } \\
\text { (2016) [33] }\end{array}$ & $\begin{array}{l}\text { United States } \\
\text { of America }\end{array}$ & $\begin{array}{l}\text { To estimate if the degree of PACT } \\
\text { (Patient Alignment Care } \\
\text { Teams) implementation at } \\
\text { a facility varied with the } \\
\text { percentage of minority } \\
\text { veteran patients at the facility. }\end{array}$ & Primary care facilities and & $\begin{array}{l}\text { Continuity of } \\
\text { care }\end{array}$ & $\begin{array}{l}\text { Validated } \\
\text { Questionnaire }\end{array}$ & $\begin{array}{l}\text { Primary Care } \\
\text { Assessment Tool } \\
\text { (Pi2 - provider } \\
\text { tool) }\end{array}$ \\
\hline $\begin{array}{l}\text { Jahromi } \\
\text { (2017) [34] }\end{array}$ & Iran & $\begin{array}{l}\text { To determine the continuity } \\
\text { of health care in urban } \\
\text { health centres in Iran }\end{array}$ & $\begin{array}{l}\text { Patients and family } \\
\text { physicians from } \\
\text { participating primary }\end{array}$ & $\begin{array}{l}\text { Interpersonal } \\
\text { continuity } \\
\text { of care }\end{array}$ & $\begin{array}{l}\text { Validated } \\
\text { questionnaire }\end{array}$ & $\begin{array}{l}\text { Primary Care } \\
\text { Evaluation Tool } \\
\text { (PCET) }\end{array}$ \\
\hline
\end{tabular}


Table 1 Characteristics of included studies assessing the quality of continuous relationships between patients and providers in primary care grouped by inclusion criteria and in alphabetical order of first author (Continued)

\begin{tabular}{|c|c|c|c|c|c|c|}
\hline Author (Year) & Country & Aim of study & $\begin{array}{l}\text { Sample } \\
\text { (Participants) }\end{array}$ & $\begin{array}{l}\text { Phrases used to } \\
\text { indicate "quality } \\
\text { relationships" }\end{array}$ & $\begin{array}{l}\text { Type of } \\
\text { relevant } \\
\text { questionnaire(s) }\end{array}$ & $\begin{array}{l}\text { Name of } \\
\text { relevant } \\
\text { questionnaire(s) }\end{array}$ \\
\hline $\begin{array}{l}\text { Kristjansson } \\
\text { (2013) [6] }\end{array}$ & Canada & $\begin{array}{l}\text { To assess whether there was a } \\
\text { difference in the continuity } \\
\text { of care provided by different } \\
\text { models of primary care }\end{array}$ & $\begin{array}{l}\text { Health professionals and } \\
\text { patients } \geq 18 \text { years of age, } \\
\text { cognitively intact and } \\
\text { not acutely ill }\end{array}$ & $\begin{array}{l}\text { Continuity } \\
\text { of care } \\
\text { Relational } \\
\text { continuity }\end{array}$ & $\begin{array}{l}\text { Validated } \\
\text { questionnaire }\end{array}$ & $\begin{array}{l}\text { Primary Care } \\
\text { Assessment Tool } \\
\text { (PCAT) }\end{array}$ \\
\hline Liu (2017) [35] & China & $\begin{array}{l}\text { To understand the relationship } \\
\text { preferences of primary care } \\
\text { patients and their associations } \\
\text { with patient experience } \\
\text { of continuity of care. }\end{array}$ & $\begin{array}{l}\text { Patients aged } \geq 18 \text { years } \\
\text { attending a community } \\
\text { health clinic in Beijing, } \\
\text { and not acutely ill. }\end{array}$ & $\begin{array}{l}\text { Continuity } \\
\text { of care } \\
\text { Relational } \\
\text { continuity } \\
\text { Continuing } \\
\text { relationship }\end{array}$ & $\begin{array}{l}\text { Validated } \\
\text { questionnaire }\end{array}$ & $\begin{array}{l}\text { Care Continuity } \\
\text { Across Levels } \\
\text { of Care Scale } \\
\text { (CCAENA) }\end{array}$ \\
\hline $\begin{array}{l}\text { Merriel (2015) } \\
{[36]}\end{array}$ & $\begin{array}{l}\text { United } \\
\text { Kingdom }\end{array}$ & $\begin{array}{l}\text { To assess whether differences } \\
\text { in the depth of relationship } \\
\text { between a patient and their } \\
\text { GP affects the length of } \\
\text { consultations, and the } \\
\text { number and type of } \\
\text { problems and issues raised } \\
\text { during a consultation. }\end{array}$ & $\begin{array}{l}\text { Patients aged } \geq 18 \text { years } \\
\text { with a PHP appointment } \\
\text { at a participating primary } \\
\text { care clinic. }\end{array}$ & $\begin{array}{l}\text { Patient-doctor } \\
\text { continuity } \\
\text { Patient-doctor } \\
\text { relationship }\end{array}$ & $\begin{array}{l}\text { Validated } \\
\text { questionnaire }\end{array}$ & $\begin{array}{l}\text { Patient-Doctor } \\
\text { Depth of } \\
\text { Relationship }\end{array}$ \\
\hline $\begin{array}{l}\text { Uijen (2012) } \\
\text { [19] }\end{array}$ & Netherlands & $\begin{array}{l}\text { To explore heart failure } \\
\text { patients' experiences with } \\
\text { continuity of care, and its } \\
\text { relation to medication } \\
\text { adherence. }\end{array}$ & $\begin{array}{l}\text { Primary care patients with } \\
\text { chronic heart failure, literate } \\
\text { in Dutch, no terminal } \\
\text { diagnosis, and no } \\
\text { mental impairment. }\end{array}$ & $\begin{array}{l}\text { Continuity } \\
\text { of care } \\
\text { Personal } \\
\text { continuity }\end{array}$ & $\begin{array}{l}\text { Non-validated } \\
\text { Questionnaire }\end{array}$ & N/A \\
\hline $\begin{array}{l}\text { Uijen (2014) } \\
\text { [37] }\end{array}$ & Netherlands & $\begin{array}{l}\text { To explore the level of } \\
\text { experienced continuity } \\
\text { of care of patients at risk for } \\
\text { depression in primary care, } \\
\text { and compare these to those } \\
\text { of patients with heart failure }\end{array}$ & $\begin{array}{l}\text { Patients with diagnosed } \\
\text { depression or heart failure } \\
\text { within the last } 12 \text { months, } \\
\text { literate in Dutch, no } \\
\text { terminal diagnosis, and } \\
\text { no mental impairment. }\end{array}$ & $\begin{array}{l}\text { Continuity } \\
\text { of care } \\
\text { Personal } \\
\text { continuity }\end{array}$ & $\begin{array}{l}\text { Questionnaire } \\
\text { (adapted abut } \\
\text { not re-validated) }\end{array}$ & $\begin{array}{l}\text { Nijmegen } \\
\text { Continuity } \\
\text { Questionnaire } \\
\text { (Brief version) }\end{array}$ \\
\hline $\begin{array}{l}\text { Wei (2015) } \\
\text { [38] }\end{array}$ & China & $\begin{array}{l}\text { To assess changes in the } \\
\text { quality of primary care in two } \\
\text { megacities following the } \\
\text { introduction of health } \\
\text { system reforms in China. }\end{array}$ & $\begin{array}{l}\text { Patients aged } \geq 18 \text { years, } \\
\text { attending community } \\
\text { health centres in Shenzhen, } \\
\text { or Shanghai }\end{array}$ & $\begin{array}{l}\text { Long-term } \\
\text { relationships } \\
\text { between } \\
\text { patients and } \\
\text { general } \\
\text { practitioners } \\
\text { Continuity }\end{array}$ & $\begin{array}{l}\text { Questionnaire } \\
\text { (adapted but } \\
\text { not re-validated) }\end{array}$ & $\begin{array}{l}\text { Primary Care } \\
\text { Assessment Tool } \\
\text { (Chinese } \\
\text { translation) }\end{array}$ \\
\hline
\end{tabular}

additional pilot work prior to use. These three questionnaires are the Care Continuity Across Levels of Care Scale (CCAENA), the Nijmegan Continuity Questionnaire and the Patient-Doctor Depth of Relationship Tool.

The decision to use one of the reviewed questionnaires in future work requires careful consideration. Some of the questionnaires focussed solely on assessing quality of relationships and did not examine any other topics, for example the Patient Doctor Relationship Questionnaire (PDRQ-9) [39]. However, for this questionnaire, no evidence of pilot testing was found that confirmed the content was relevant and sufficiently comprehensive to assess the experiential nature of relationship quality. Questionnaires with a broader focus could be interpreted as less relevant, such as the Nijmegan Continuity questionnaire ( $28 \%$ relevant items), however this questionnaire has confirmed construct validity and test-retest validity, demonstrating its appropriateness for future use in research [20, 40]. Researchers and primary care workers are encouraged to consider several factors that may impact on the use of these questionnaires in their work, including their scope, focus, length, availability and validity testing.

Caution is needed when interpreting the level of validity testing undertaken for the questionnaires used in the studies in the review. Diverse terms were used to describe the same type of validity testing (such as internal consistency and construct validity) [15, 20, 31, 40]. Furthermore, only two studies assessed test-retest reliability, the Nijmegan Continuity Questionnaire and Patient-doctor depth of relationship tool. Confirming test-retest reliability is considered essential for evaluations of interventions in order to be confident that any changes seen in results over time is due to a change in service rather than natural variation of results [41]. Undertaking validity testing does not guarantee that a questionnaire is "valid". For example, the authors of the Generic Measure of Continuity Scale conducted a pilot study to investigate its correlation with pre-identified indicators of continuity and found very low correlation [15]. No 


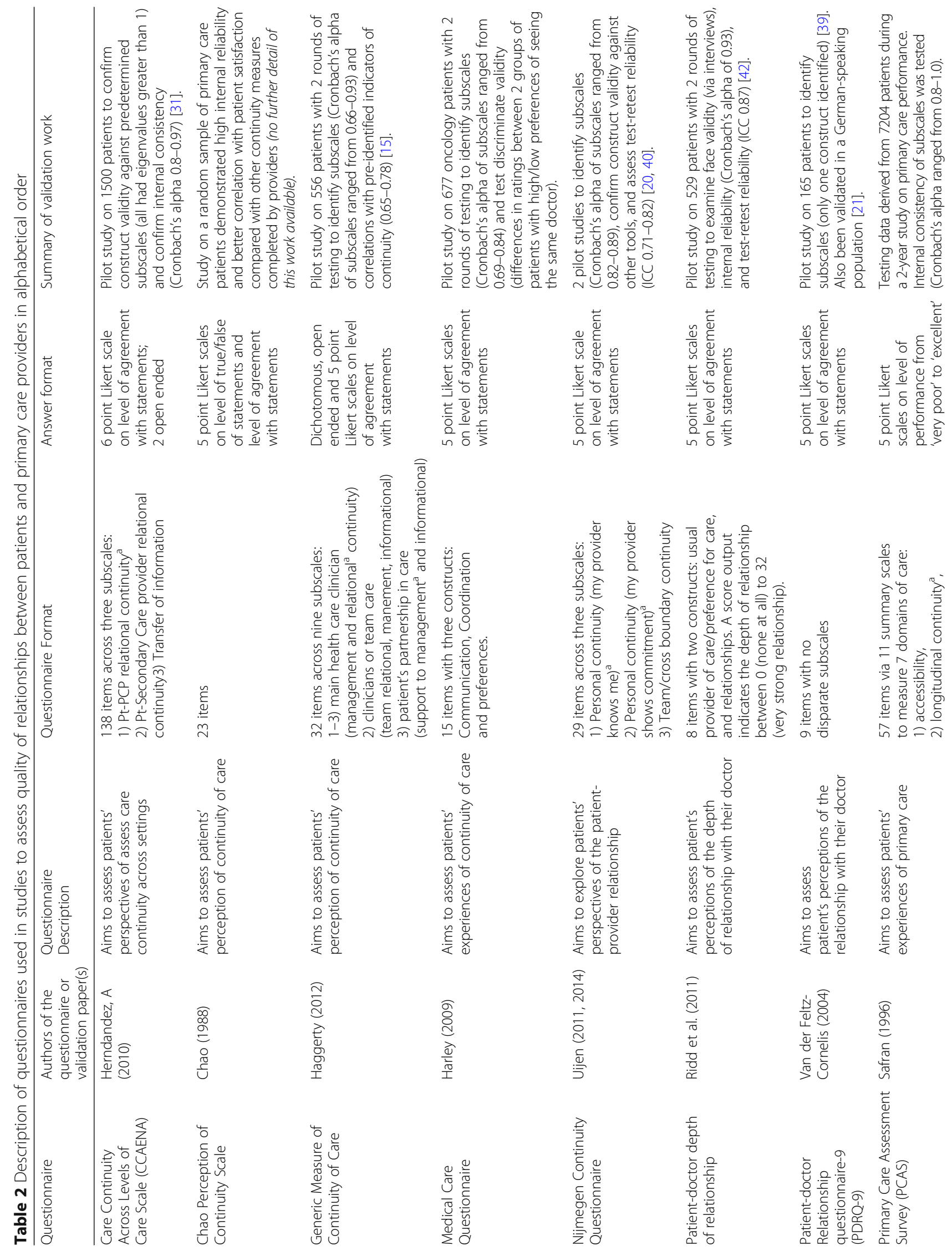




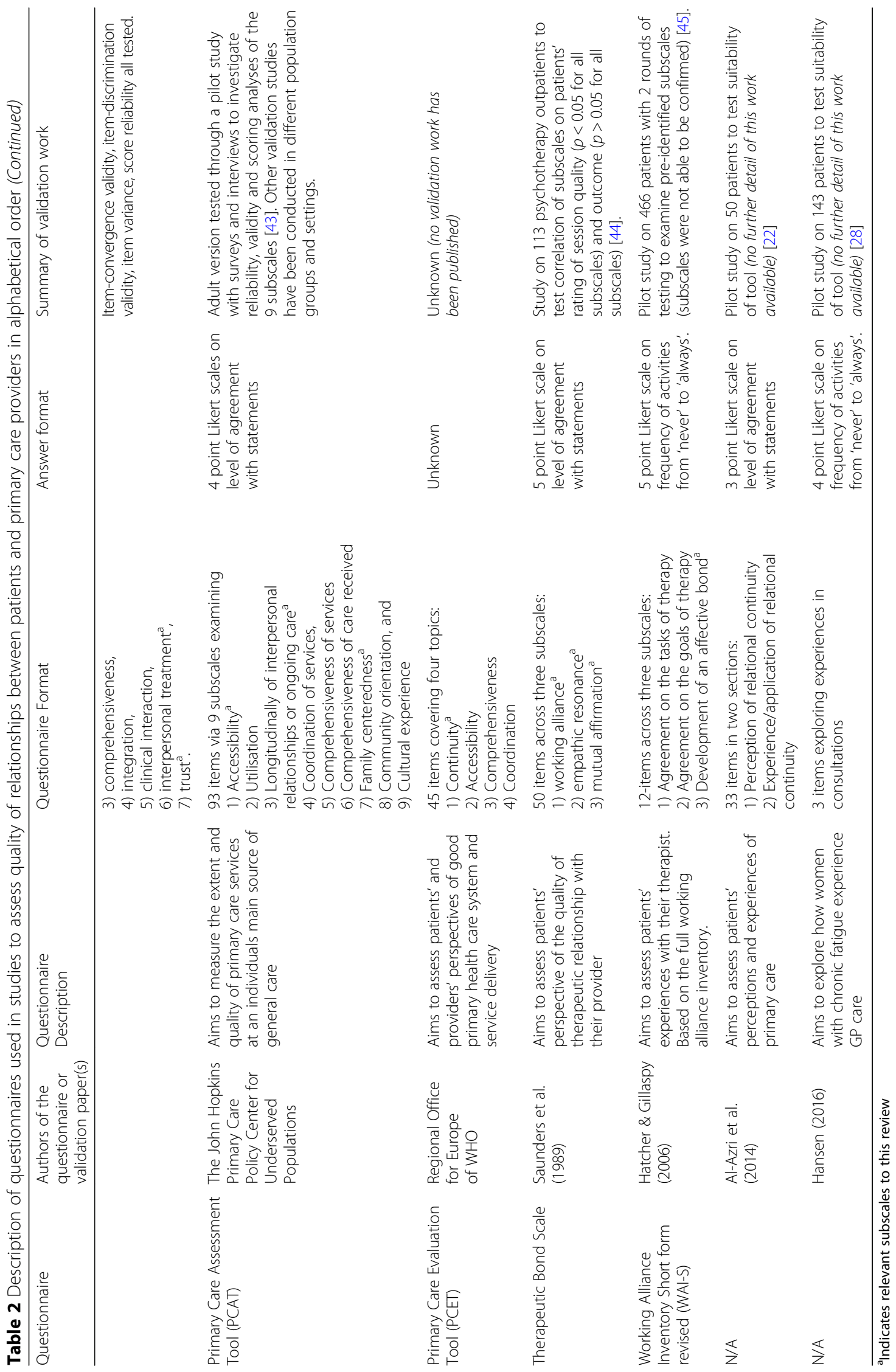


Table 3 Overview of questionnaires that assess quality of relationships

\begin{tabular}{|c|c|c|c|c|c|c|}
\hline Questionnaire & $\begin{array}{l}\text { Estimated } \\
\text { completion time }\end{array}$ & $\begin{array}{l}\text { Number } \\
\text { of items }\end{array}$ & $\begin{array}{l}\text { Number of relationship } \\
\text { focussed items (\%) }\end{array}$ & Freely available & $\begin{array}{l}\text { Languages } \\
\text { available }\end{array}$ & $\begin{array}{l}\text { Additional pilot } \\
\text { work likely } \\
\text { required prior } \\
\text { to use }\end{array}$ \\
\hline $\begin{array}{l}\text { Care Continuity Across Levels } \\
\text { of Care Scale (CCAENA) }\end{array}$ & $10-15 \mathrm{~min}$ & 73 & $10(14 \%)$ & Yes [46] & English, Spanish & No \\
\hline $\begin{array}{l}\text { Chao-Perception of } \\
\text { Continuity Scale }\end{array}$ & $10-15 \min$ & 23 & $20(87 \%)$ & Yes [47] & English & $Y_{e s}^{b}$ \\
\hline $\begin{array}{l}\text { Generic Measure of } \\
\text { Continuity Scale }\end{array}$ & $15 \min$ & 32 & $11(34 \%)$ & $\begin{array}{l}\text { No -subscription } \\
\text { required [15] }\end{array}$ & English, French & Yes $^{\mathrm{b}}$ \\
\hline Medical care questionnaire & $<5 \min$ & 15 & $4(26 \%)$ & Yes [16] & English & $Y_{e s}^{b}$ \\
\hline $\begin{array}{l}\text { Nijmegen Continuity } \\
\text { Questionnaire }\end{array}$ & $15 \min$ & 29 & $8(28 \%)$ & Yes [48] & $\begin{array}{l}\text { English, Dutch, } \\
\text { Norwegian }\end{array}$ & No \\
\hline $\begin{array}{l}\text { Patient-Doctor Depth } \\
\text { of Relationship }\end{array}$ & $<5 \min$ & 8 & $7(88 \%)$ & Yes [49] & English & No \\
\hline $\begin{array}{l}\text { Patient Doctor Relationship } \\
\text { Questionnaire (PDRQ-9) }\end{array}$ & $<5 \min$ & 9 & $9(100 \%)$ & Yes [39] & English & Yes $^{b}$ \\
\hline Therapeutic Bond scale & $30 \mathrm{~s}$ & 6 & Unknown & $\begin{array}{l}\text { No - payment } \\
\text { required [50] }\end{array}$ & English & Yes $^{b}$ \\
\hline $\begin{array}{l}\text { Working Alliance Inventory - } \\
\text { Short Form revised }\end{array}$ & $5 \mathrm{~min}$ & 12 & $8(66 \%)$ & Yes [51] & $\begin{array}{l}\text { English, Argentinian, } \\
\text { Chilean, Chinese, Danish, } \\
\text { Dutch, Finish, French, } \\
\text { German, Italian, Japanese } \\
\text { Lithuanian, Norwegian, Polish } \\
\text { Portuguese, Slovenian, } \\
\text { Spanish, Urdu }\end{array}$ & Yes $^{\mathrm{b}}$ \\
\hline
\end{tabular}

astimated completion time based description of questionnaire where possible, or authors' interpretation

${ }^{b}$ No evidence of establishing reliability of construct validity, which may preclude its use in evaluation work

changes were made to the scale to ameliorate the low correlation, which hampers its use without further development work. Conversely, the Patient-doctor depth of relationship tool has undertaken the most comprehensive pilot testing work of all the reviewed questionnaires and has confirmed good face validity, high internal reliability and strong test-retest reliability, indicating its appropriateness for future use [42].

This is a comprehensive review which identified six questionnaires that were not captured in the previous review [12]. Two of the questionnaires were included in the previous systematic review (Patient-doctor depth of relationship tool and Patient doctor relationship questionnaire (PDRQ-9)) and continue to be used in studies $[21,36]$. The remaining questionnaires have been developed or refined since this time, indicating an increasing focus on this aspect of health care evaluation. However, this review has also identified some notable limitations regarding questionnaires assessing quality of relationships between patients and primary care providers. None of the questionnaires consider providers' perspectives relationships, or the association between patients' and providers' perspectives on their relationship. Furthermore, none of the studies investigated whether the quality of relationship predicted patient outcomes, warranting future work to confirm the notion that quality of relationships is associated with improved outcomes.

\section{Conclusions}

This study provides an overview of 14 unique questionnaires that have been used to assess the quality of relationships between patients and primary care providers. This area is of increasing importance with the growing focus on patient engagement as a critical element in the prevention and management of chronic disease and unhealthy lifestyle choice. The selection of a questionnaire for future work should be based on its scope, focus, length and feasibility for use in the setting in which it will be applied.

\section{Abbreviations \\ CCAENA: Care Continuity Across Levels of Care Scale [translated from Spanish: Cuestionario Continuidad Asistencial Entre Niveles de Atención]; CINAHL: Cumulative Index of Nursing and Allied Health Literature; PDRQ- 9: Patient Doctor Relationship Questionnaire - 9 item; PRIMSA: Preferred Reporting Items for Systematic Reviews and Meta-Analyses}

\section{Acknowledgements}

The authors wish to acknowledge the Griffith University health librarian who provided assistance with the literature search.

Funding

Not applicable

\section{Availability of data and materials}

Data sharing is not applicable to this article as no datasets were generated or analysed during the current study. 


\section{Authors' contributions}

$\mathrm{LB}$ and $\mathrm{KB}$ performed the literature search, review and extraction. CN, LC and CJ made substantial contributions to the conception and design of the review and interpretation of the findings. All authors participated in regular meetings about interpretation of tools and manuscript writing. All authors were involved in the drafting of the manuscript and read and approved the final manuscript. All authors have agreed they are accountable for all aspects of the work.

\section{Ethics approval and consent to participate}

Not applicable

\section{Consent for publication}

Not applicable

\section{Competing interests}

The authors declare that they have no competing interests.

\section{Publisher's Note}

Springer Nature remains neutral with regard to jurisdictional claims in published maps and institutional affiliations.

\section{Received: 15 April 2018 Accepted: 5 November 2018} Published online: 19 November 2018

\section{References}

1. Agency for Healthcare Research and Policy. The Medical Home: What Do We Know, What Do We Need to Know? USA: Agency for Healthcare Research and Policy; 2013.

2. World Health Organization. Primary health care: now more than ever. Geneva: World Health Report; 2008.

3. Martin D, Garske J, Davis M. Relation of the therapeutic alliance with outcome and other variables: a meta-analytic review. Am Psychol Assoc. 2000;68(3):438-50.

4. Fuertes J, Mislowack A, Bennett J, Paul L, Gilbert T, Fontan G, Boylan L. The physician-patient working alliance. Patient Educ Couns. 2007;66(1):29-36.

5. Alazri M, Heywood P, Neal R, Leese B. Continuity of care: literature review and implications. Sultan Qaboos Univer Med J. 2007;7(3):197-206.

6. Kristjansson E, Hogg W, Dahrouge S, Tuna M, Mayo-Bruisma L, Gebremichael G. Predictors of relational continuity in primary care: patient, provider and practice factors. BMC Fam Pract. 2013;14:72.

7. Shellner P. Relationship-based care: a model for transforming practice. Creative Health Care Management: USA; 2007

8. Scott J, Cohen D, DiCicco-Bloom B, Miller W, Stange K, Crabtree B. Understanding healing relationships in primary care. Ann Fam Med. 2008; 6(4):315-22.

9. Griffith S. A review of the factors associated with patient compliance and the taking of prescribed medicines. Br J Gen Pract. 1990;40(332):114-6.

10. The Commonwealth Fund. Recommended Core Measure for Evaluating the Patient-Centred Medical Home: Cost, Utilization and Clinical Quality. United States: The Commonwealth Fund; 2012.

11. Goldman R, Parker D, Brown J, Walker J, Eaton C, Borkan J. Recommendations for a mixed methods approach to evaluating the patient-centered medical home. Ann Fam Med. 2015;13(2):168-75.

12. Eveleigh R, Muskens $E$, van Revesteijn H, van Dijk I, van Riswijk E, Lucassen P. An overview of 19 instruments assessing the doctor-patient relationship: different models or concepts are used. J Clin Epidemiol. 2012;65(1):10-5.

13. Moher D, Liberati A, Tetzlaff J, Altman D. Preferred Reporting Items for Systematic Reviews and Meta-Analyses: The PRISMA Statement. PLoS Med. 2009:6(7). https://doi.org/10.1371/journal.pmed.1000097.

14. Burge F, Haggerty J, Pineult R, Beaulieu M, Levesque J, Beaulieu C, et al. Relational continuity from the patient perspective: comparison of primary healthcare evaluation instruments. Healthc Policy. 2011;7(Spec Issue):124-38.

15. Haggerty J, Roberge D, Freeman G, Beaulieu C, Breton M. Validation of a generic measure of continuity of care: when patients encounter several clinicians. Ann Fam Med. 2012;10(5):443-51.

16. Harley C, Adams J, Booth L, Selby P, Brown J, Velikova G. Patient experiences of continuity of cancer care: development of a new medical care questionnaire (MCQ) for oncology outpatients. Value Health. 2009;12(8):1180-6.

17. Hill K, Twiddy M, Hewison J, O'House A. Measuring patient-perceived continuity of care for patients with long-term conditions in primary care. BMC Fam Pract. 2014;15:191-9.
18. Jatrana S, Crampton P, Richardson P. Continuity of care with general practitioners in New Zealand: results from SoFIE-primary care. N Z Med J. 2011;124(1329):16-25.

19. Uijen AA, et al. Heart failure patients' experiences with continuity of care and its relation to medication adherence: a cross-sectional study. BMC Fam Pract. 2012;13:86.

20. Uijen A, Bosh M, van den Bosch W, Bor H, Wensing M, Schers H. Nijmegen continuity questionnaire: development and testing of a questionnaire that measures continuity of care. J Clin Epidemiol. 2011;64(12):1391-9.

21. Zenger $M$, Schaefert $R$, van der Feltz-Cornelis C, Brahler E, Hauser W. Validation of the Patient-Doctor-Relationship Questionnaire (PDRQ-9) in a representative cross-sectional German population survey. PLoS One. 2014; 9(3). https://doi.org/10.1371/journal.pone.0091964.

22. Al-Azri M, Al-Ramadhani R, Al-Rawahi N, Al-Shafee K, Al-Hinai M, Al-Maniri A Patients' attitudes and experiences of relational continuity in semi-urban general practices in Oman. Fam Pract. 2014;31(3):303-10.

23. Berchtold P, Kunzi B, Busato A. Differences of the quality of care experience: the perception of patients with either network or conventional health plans. Fam Pract. 2011:28(4):406-13.

24. Bryan C, Corso K, Corso M, Kanzler K, Ray-Sannerud B, Morrow C. Therapeutic alliance and change in suicidal ideation during treatment in integrated primary care settings. Arch Suicide Res. 2012;16(4):316-23.

25. Corso K, Bryan C, Corso M, Kanzler K, Houghton D, Ray-Sannerud B, Morrow C. Therapeutic alliance and treatment outcome in the primary care behavioral health model. Fam Syst Health. 2012;30(2):87-100.

26. Falkenström F, Granström F, Holmqvist R. Therapeutic alliance predicts symptomatic improvement session by session. J Couns Psychol. 2013;60(3): 317-28.

27. Ferrer A, Brentani A, Sucupira A, Navega A, Cerqueira E, Grisi S. The effects of a people-centred model on longitudinality of care and utilization pattern of healthcare services--Brazilian evidence. Health Policy Plan. 2014;29(Suppl 2):ii107-13.

28. Hansen A, Lian O. Experiences of general practitioner continuity among women with chronic fatigue syndrome/myalgic encephalomyelitis: a crosssectional study. BMC Health Serv Res. 2016;16(1):650-8.

29. Aller M, Vargas I, Waibel S, Coderch J, Sanchez-Perez I, Colomes L, et al. A comprehensive analysis of patients' perceptions of continuity of care and their associated factors. Int J Qual Health Care. 2013;25(3):291-9.

30. Aller M, Colome J, Waibel S, Vargas I, Vazquez M. A first approach to differences in continuity of care perceived by immigrants and natives in the Catalan public healthcare system. Int J Environ Res Public Health. 2013;10(4): 1474-88.

31. Aller M, Vargas I, Garcia-Subirats I, Coderch J, Colomes L, Llopart J, et al. A tool for assessing continuity of care across care levels: an extended psychometric validation of the CCAENA questionnaire. Int J Integr Care. 2013;13:e050.

32. Aller M, Vagas I, Coderch-Lassaletta J, Sanchez-Perez I, Llipart J, Colomes L, et al. Factors associated to experienced continuity of care between primary and outpatient secondary care in the Catalan public healthcare system. Gac Sanit. 2013;27(3):207-13.

33. Hernandez S, Taylor L, Grembowski D, Redi R, Wong E, Nelson K, et al. A first look at PCMH implementation for minority veterans: room for improvement. Med Care. 2016:54(3):253-61.

34. Jahromi V, Mehrolhassani M, Dehnavieh R, Anari H. Continuity of Care Evaluation: The View of Patients and Professionals about Urban Family Physician Program. Int J Prev Med. 2017;8. https://doi.org/10.4103/20087802.200525.

35. Liu C, Wu Y, Chi X. Relationship preferences and experience of primary care patients in continuity of care: a case study in Beijing, China. BMC Health Serv Res. 2017;17(1):585-96.

36. Merriel S, Salisbury C, Metcalfe C, Ridd M. Depth of the patient-doctor relationship and content of general practice consultations: cross-sectional study. Br J Gen Pract. 2015;65(637):e545-51.

37. Uijen A, Schers $H$, Schene A, Schellevis F, Lucassen P, van den Bosch W Experienced continuity of care in patients at risk for depression in primary care. Eur J Gen Pract. 2014;20(3):161-6.

38. Wei $\mathrm{X}, \mathrm{Li} \mathrm{H}$, Yang N, Wong S, Owolabi $\mathrm{O}, \mathrm{Xu}$ J, et al. Comparing quality of public primary care between Hong Kong and Shanghai using validated patient assessment tools. PLoS One. 2015;10(3):e0121269.

39. van der Feltz-Cornelis C, Van Oppen P, Van Marwoijk H, De Beurs E, Van Dyck R. A patient-doctor relationship questionnaire (PDRQ-9) in primary 
care: development and psychometric evaluation. Gen Hosp Psychiatry. 2004; 26:115-20.

40. Uijen A, Schers H. Measuring continuity of care: psychometric properties of the Nijmegen continuity questionnaire. Br J Gen Pract. 2012;62(600):e949-57.

41. Campbell N, Murray E, Darbyshire J, Emery J, Farmer A, Griffiths F, et al. Designing and evaluating complex interventions to improve health care. BMJ. 2007;334(7591):455-9.

42. Ridd M, Lewis G, Peters T, Salisbury C. Patient-doctor depth-of-relationship scale: development and validation. Ann Fam Med. 2011;9(5):538-45.

43. Drph L, Starfield B, Xu J. Validating the adult primary care assessment tool. J Fam Pract. 2001;50(2):161.

44. Saunders S, Howard K, Orlinsky D. Therapeutic bond scales: psychometric characteristics and relationship to treatment effectiveness. Psychol Assess. 1989; 1 (4):323-30.

45. Hatcher R, Gillaspy J. Development and validation of a revised short version of the working alliance inventory. Psychother Res. 2006;16(1):12-25.

46. Navarrete M, Vargas I, Aller Hernandez M, Coderch de Lassaletta J, Sanchez I, et al. CCAENA Questionnaire - Continuity of Care Between Care Levels. 2010. Available from: http://www.consorci.org/media/upload/arxius/publicacions/ Questionnaire\%20CCAENA\%20English.pdf. [cited on 20/09/2018].

47. McDonald KM, et al. Appendix IV: Care Coordination Measures Instruments. In: Care Coordination Measures Atlas (pp. 390). 2014. Available from: https:// primarycaremeasures.ahrq.gov/care-coordination/downloads/ccatlas/Care_ Coordination_Atlas_Appendix_IV.pdf. [cited on 20/09/2018].

48. Uijen A, Bosh M, van den Bosch W, Bor H, Wensing M, Schers H. Nijmegen Continuity Questionnaire: development and testing of a questionnaire that measures continuity of care (certified post print, supplementary material). Available from https://postprint.nivel.n//PPpp4411.pdf?. [cited on 20/09/2018].

49. University of Bristol. Patient-Doctor Depth of Relationship scale n.d. Available from: http://www.bristol.ac.uk/primaryhealthcare/resources/pddr/. [cited on 20/09/2018].

50. Celeste Solutions. Our Instruments - Therapeutic Bond Scale 2017. Available from: http://www.celesthealth.com/instruments.asp. [cited on 20/09/2018].

51. Horvath A. Working Alliance Inventory - Short Revised (WAI-SR) 2009. Available from: http://wai.profhorvath.com/sites/default/files/upload/WAlSR\%20Client\%20Version.pdf. [cited on 20/09/2018].

Ready to submit your research? Choose BMC and benefit from:

- fast, convenient online submission

- thorough peer review by experienced researchers in your field

- rapid publication on acceptance

- support for research data, including large and complex data types

- gold Open Access which fosters wider collaboration and increased citations

- maximum visibility for your research: over $100 \mathrm{M}$ website views per year

At BMC, research is always in progress.

Learn more biomedcentral.com/submissions 